\title{
Technologies developed to avoid frost damages caused by late frost during bloom in the fruit growing regions of Siófok and Debrecen
}

\author{
Lakatos, L. ${ }^{1}$, Hadvári, M. ${ }^{2}$, Szél, J.1, Gonda,I. ${ }^{3}$, Szabó, Z ${ }^{3}$, Soltész, M. ${ }^{3}$, Sun, Z. ${ }^{4}$ \\ Zhang, J. ${ }^{5}$, Nyéki, J. ${ }^{3} \&$ Szukics, J. ${ }^{6}$ \\ ${ }^{1}$ University of Debrecen, Centre of Agricultural and Applied Economic Sciences, Department of Agricultural \\ Engeneering H-4032 Debrecen, Böszörményi 138, Hungary, lakatos@agr.unideb.hu \\ ${ }^{2}$ Main Observatory of Marczell György Department of Remote Sensing 1181 Budapest, Gilice tér 39. \\ ${ }^{3}$ University of Debrecen, Institute of Horticulture, H-4032 Debrecen, Böszörményi 138, Hungary \\ ${ }^{4}$ Inst. of Environment and Development in Agriculture (IEDA), Chinese Academy of Agricultural Sciences (CAAS), \\ No. 12, Zhong-guan-cun South Street Beijing 100081 P.R. China \\ ${ }^{5}$ College of Horticulture Shandong Agriculture University, Taian, Shandong Province 271018P.R. China \\ ${ }^{6}$ Siófoki Fruit Growing GmbH, H-8600 Siófok, Május 1 str. 0306/65.
}

\begin{abstract}
Summary: The aim of the study was to find out which of the methods used to avoid damages of late frosts would be the most effective for the fruit growing practice. Three technologies have been tested in the regions of Siófok and Debrecen-Pallag. The antifrost irrigation proved to be the most advantageous. For that purpose microjet sprayers are used, which are thrifty and do not need for that purpose large containers. With the aim to secure an even distribution of water, the sprayers are distributed on three levels: above and inside of the crown as well as on the level of trunks. On a large scale, a single microjet above the crown level would be sufficient. By means of a detailed analysis served to set the optimum intervals between spraying phases: with each 15, 10,5 and 3 minutes during half a minute. The synchronous presence of water and ice below the freezing point, the released freezing heat plus the water used much above the freezing point $\left(9-10^{\circ} \mathrm{C}\right)$ altogether maintains the temperature above around $0^{\circ} \mathrm{C}$ near the flowers or growing fruitlets, meanwhile, the surrounding air cools down to $-8^{\circ} \mathrm{C}$. The effectiveness of the generally used anti-frost would be increased substantially by the former application of cooling irrigation, which delays the blooming date. The Frostbuster represents a new technology developed for the same purpose of frost defence. It uses butane burning and produces high $\left(80-90^{\circ} \mathrm{C}\right)$ temperature with a strong blast of air. On the protected area sensors have been distributed for measuring temperature and relative humidity. The means of the measurements proved a rise of temperature, which was sufficient to save the fruit trees until the difference is less than $-3-3.5^{\circ} \mathrm{C}$. Our analyses stated that paraffin candles avert the frost until $-4{ }^{\circ} \mathrm{C}$. Its success depends largely on the intensity of air movements. A small wind would be enough to frustrate the effect. The results show clearly the utility of Frostbuster and paraffin candle combined is approved.
\end{abstract}

Key words: spring frost protection, Frostbuster, paraffin candle, antifrost irrigation, microjet sprayers

\section{Introduction, survey of the literature}

Frost defence is a serious challenge for the fruit grower. The problem is compound first of all, as the grower needs a prediction to be prepared (Young 1920), Hagood (1967) or having an idea about the severity expected (Allen 1957). The frost threatens with more different damages in the horticulture than any other adversity in the USA (White \& Hass 1975), as well as in other parts of the world. The prevention of frost (Rieger 1989, Kalma et al. 1992, Snyder \& de MeloAbreu 2005) and mitigation of damages is possible by passive (indirect) or by active (direct) intervention. Passive prevention begins with the choice of the species and variety and the growing site, which means always to tackle the risks related to those decisions. The preparation of technical tools and finding the optimum of agrotechnical interventions including anti frost equipment or retarding blooming time, etc. (Lakatos et al. 2010). Heavy damages are often caused by the lack of any planned defence. Active interventions are actual any time when low temperatures threaten with freezing the tissues of the plants. Air mixing (wind machine) (Goodall et al. 1957, Crawford 1965) and irrigation are then actual (Davies et al. 1984, Cordy 1965, Brooks 1961, Gerber \& Martsolf 1979, Synder 1986), as the most applied defence mechanism, but the induction of fog, paraffin candle (Angus 1955) and the warming up by Frostbuster.

The main use of microjets was originally the irrigation (supply of water) for agricultural and horticultural plants 
during the summer. The spraying system exerts a definitive effect upon the daily variation of temperature. If the weather is warm, more than $20^{\circ} \mathrm{C}$, the application of sprinkler cools down the temperature on the level of plants effectively. The cooling effect depends also from the relative air humidity, thus the date of blooming could be delayed and the blooming period prolonged (Lakatos et al. 2010). In early spring, the danger of cool temperatures, as late frosts, may endanger the early blooming fruit trees. The earlier performed experiments with cooling sprays aimed to study its effects on the quality of the fruit (Iglesias et al. 2002). With sprinklers above the trees may improve the cover colour of the ripening fruits (Iglesias et al. 2005), the content of anthocyans increased (Iglesias et al. 2008).

Irrigation applied as an anti-frost procedure is most effective in avert damages caused by nocturnal radiation (Gerber \& Harrison 1964). Irrigation ought to be started before the temperature dropped to $0{ }^{\circ} \mathrm{C}$ (Gerber \& Harrison 1964). Irrigation is continued until the air temperature rises above $0{ }^{\circ} \mathrm{C}$ (Gerber \& Martsolf 1979). Perry (1979) recommended the irrigation with sprinklers over the crown of trees as to avert frost damages (Bagdonas et al. 1978, Rieger \& Myers 1990). Large quantity of water is needed for that purpose, which reduces the chances of its use. Some further experiments suggested that irrigation below the crown might be also effective (Zinoni \& Anconelli 1997, Anconelli \& Zinoni 1998). Moreover, the cooling effect on the microclimate is sufficient with much lower doses of water, as for the prevention of weak frost damages. In addition, further phytosanitary effects are also expected with this method.

The Frostbuster seems to become a popular success among the anti-frost methods against frost caused by nocturnal radiation. Its success is conditioned by a complete windless period. An important factor is also the volume of the foliage. The more leaves the better the heating effect. Frostbuster is a turbine mounted on a tractor, which makes warm air blasts. It needs a machine of 55 h.p. and 540 r.p.m. (revolution per minute). His maximal carrying power is 150 $\mathrm{m}$. It consumes $30 \mathrm{~kg}$ per hour propane gas. The heated air temperature at the opening is around 80 and $100{ }^{\circ} \mathrm{C}$, but 1 meter away $20{ }^{\circ} \mathrm{C}$, which does not hurt the plants. The warm air forms an extending bubble and pushes the cold air away

\section{Material and method}

The anti-frost experiments have been performed at two localities. At the Fruit Growing GmbH (Siófoki Gyümölcstermesztési Zrt) in an intense cherry and apricot plantation, and at the plum orchard of the Debrecen University, Pallag. At Siófok two anti-frost techniques have been applied. First, the heating of air was performed by the Frostbuster system. The essential problem is to move the tractor continuously within the plantation at a velocity, which renders possible to appear on the same spot at every 10 minute interval. That way, the area visited (to be protected) continuously could be held at a temperature above $0{ }^{\circ} \mathrm{C}$. The alternative anti frost method was the burning of paraffin candles, however, which postulates calm weather. By economical reasons, first not all candles were lit, at every second tree only. As the cooling of air became quicker than $0.6{ }^{\circ} \mathrm{C}$ per hour, all the rest of candles were also lit on the protected area.

At Pallag, we established a field laboratory of the orchard. The temperature of the area was regulated by means of microjets. Above tree crowns, within the crowns and on the level of trunks, the sprinklers were regularly activated at set intervals alternatively (every 3, 5, 10 and 15 minute), and each time the foliage and twigs were moistened. This type of irrigation cools down the temperature of the plants by several degrees until the freezing point is attained. Below 0 ${ }^{\circ} \mathrm{C}$, the temperature is raised, partially due to the temperature of water used, which may be around $9-10{ }^{\circ} \mathrm{C}$, in addition, heat is released by the freezing process too. The periodically repeated moistening of trees may keep the temperature permanently above $0{ }^{\circ} \mathrm{C}$.

At Siófok, the 8 hectares of intense cherry plantation has been equipped with five points of observation, where the temperature and the relative air humidity was monitored and documented. The means of the 5 monitors were considered as effects of the anti-frost technology. On the 7 hectares of intense apricot plantation the installation of monitoring was similarly performed with three measuring points. Another part of a 3 hectare apricot plantation was equipped with paraffin candles, and monitored by sensors in the geometrical middle of the protected area.

At Pallag, several trees were selected and at 6 sites monitored on 3 plum trees each, where cooling irrigation was performed throughout the frosty period. For the period of the treatment four variants were planned: $15,10,5$ and 3 minutes intervals between the moistening irrigations lasting half a minute each. Each tree was equipped with two platinum sensors for temperature. The temperature below the ice sheets is a mean of 6 measurements. The check (untreated) stations were placed at least $300 \mathrm{~m}$ away from treated plants at both sites (Siófok and Pallag).

In springtime, the position above the sea level determines the dynamics of cooling down during the night because the cold air is accumulating in the depressions prolongating the frosty condition. The present spring produced the coldest night at April 10, 2012. Closely after the floating cyclone, unusually cold air arrived over the country. Temperatures measured by the countrywide meteorological service (OMSZ) at $2 \mathrm{~m}$ height over soil level are presented in Table 10. The distribution of the coldest points over the country is largely influenced by the streaming and the relief of the surface. Windless sites and depressions are most afflicted by frost. At the central region between the Danube and Tisza and on the North-Eastern plain Szatmár, temperatures below $-7{ }^{\circ} \mathrm{C}$ occurred. At the OMSZ station of Siófok the drop of temperature was near $-0.3{ }^{\circ} \mathrm{C}$ only, and the experimental plantation was about $2 \mathrm{~km}$ away from the station, where several measurements showed $-5.4{ }^{\circ} \mathrm{C}$. The proximity of the Lake Balaton moderated clearly the minima of cooling down (Figure 1). 


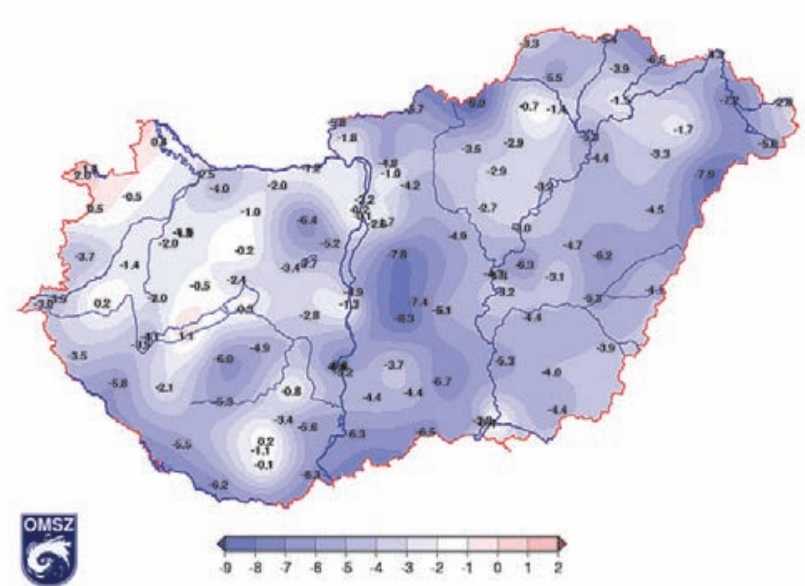

Figure 1 - Minimum temperatures in Hungary at the dawn of coldest day April 10, 1012 (Source: OMSZ)

Measurements at the soil level prove the drastic drop of temperature as the afternoon hours were still mild $\left(12-13^{\circ} \mathrm{C}\right)$ measured at $2 \mathrm{~m}$ high above the soil level. However, the next dawn produced at different sites $-10^{\circ} \mathrm{C}$ temperatures (Figure 2). The frost was particularly severe and the cold layer of air was very thick, i.e. $20-30 \mathrm{~m}$ high.

\section{Results}

Our antifrost procedure at Siófok started one and a half hours after sunset. The drop of temperature was very steep, i.e. more than $-4^{\circ} \mathrm{C}$ per hour. The activity of the Frostbuster lasted over 8 hours continuously through the whole night (Photo 1)

Measurements prove that the temperature being $-2^{\circ} \mathrm{C}$ was kept on $0{ }^{\circ} \mathrm{C}$ by the activity of the Frostbuster. When the temperature was continuously $-4{ }^{\circ} \mathrm{C}$ on the check area, the protected area showed around $-2{ }^{\circ} \mathrm{C}$ temperatures. At dawn, when the minimum attained $-5.4^{\circ} \mathrm{C}$, the area protected by the Frostbuster produced means about $-2.7^{\circ} \mathrm{C}$ (Figure 3)

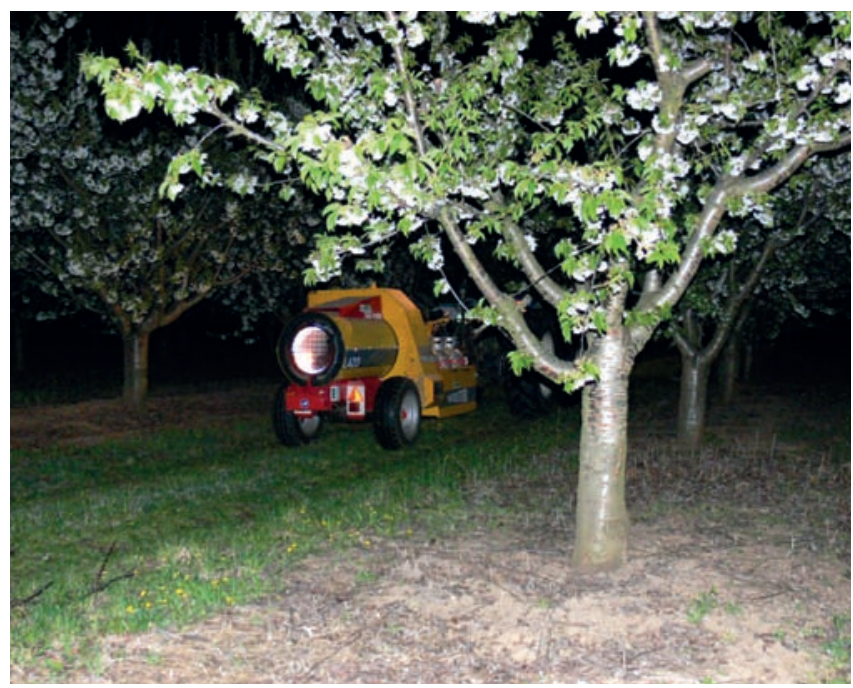

Photo 1 - Frostbuster working in the intense cherry plantation during the night April 9/10, 1012.

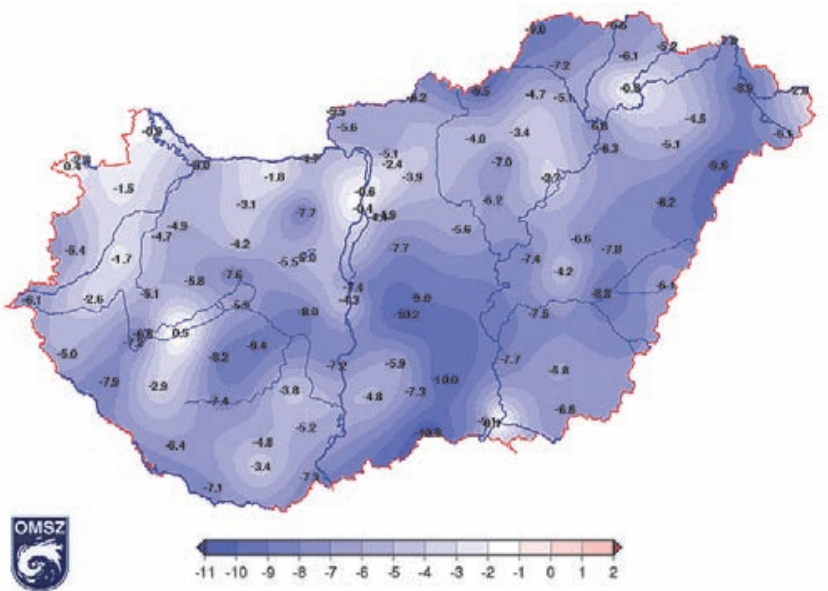

Figure 2 - Temperatures measured in Hungary on the coldest day of late spring, April 10, 1012 (Source: OMSZ)

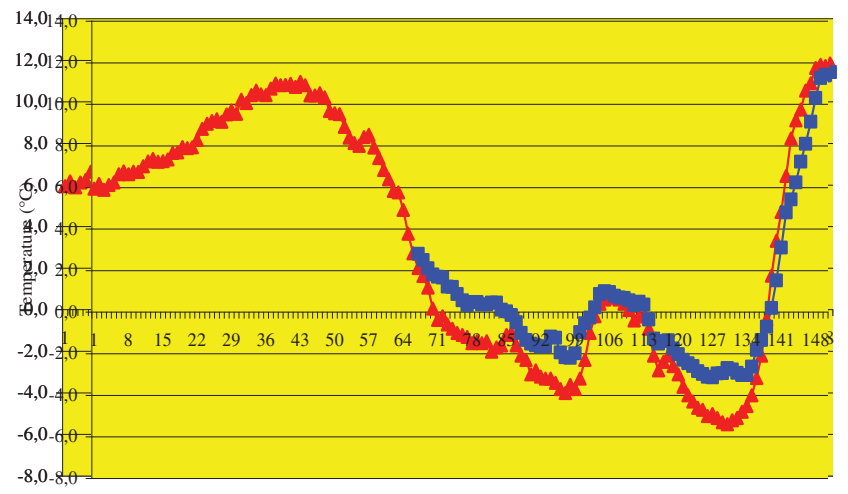

$-\rightarrow$ Check area - - Protected_cherry by Frostbuster

Figure 3-Temperatures measured in the intense cherry plantation protected by the Frostbuster (blue) and in the check area (red) during the days April 9 and 10, 1012 (between 09.00 and 09.00 hours)

The light of paraffin candles started with one hour after sunset. At every second tree a candle was lit, but after 4 hours all candles were lit because of the continuous drop of temperature (Photo 2).

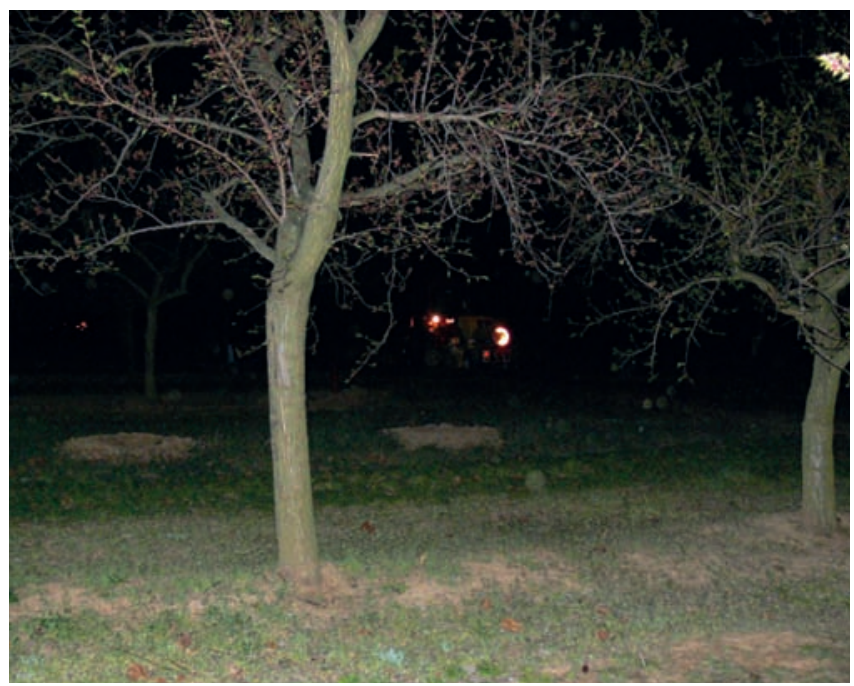

Photo 2 - Frostbuster is working in the intense apricot growing plantation at April 9-10, 2012 


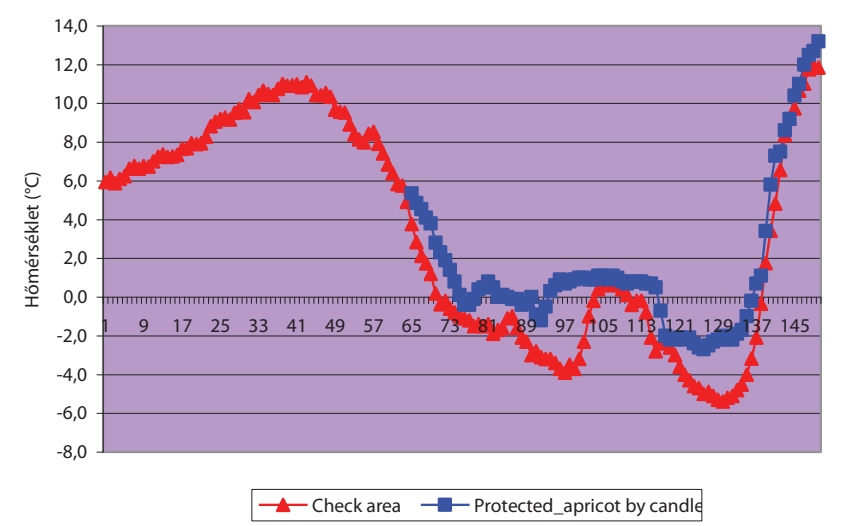

Figure 4 - The temperature measured in the intense apricot planting being protected by the paraffin candles (blue) and parallelly, of the check area (red) at Siófok between April 9, 09.00 - April 10, 09.00, 1012

Results of the measurements proved the value of the procedure. The candles kept the temperature around $1{ }^{\circ} \mathrm{C}$, when on the check area, $-4^{\circ} \mathrm{C}$ was measured (Figure 4 ).

In spite of having lit all paraffin candles after 04.00 hour because of the new drastic cooling, the heating was not able to keep the temperature above $0{ }^{\circ} \mathrm{C}$. Meanwhile the check temperature attained $-5.4{ }^{\circ} \mathrm{C}$, but on the protected area, the temperature did not drop below $-2^{\circ} \mathrm{C}$. The effectiveness of the procedure was diminished by the start of the morning wind (circulation) on the lake shore of Balaton. The mild circulation in the morning raised the temperature by nearly $5{ }^{\circ} \mathrm{C}$. After a weak blast lasting half an hour, the temperature dropped once again precipitously. Around dawn, the circulation pushed the air held around $1{ }^{\circ} \mathrm{C}$ and therefore a drop of temperature ensued (Figure 4).

The anti frost procedure performed with the Frostbuster in the apricot planting proved to be more effective than in the intense cherry planting (Photo 3). In spite of the main blooming stage of the cherry trees, as the exposed surface had a large volume, the temperature in the protected apricot planting was higher. As the Frostbuster communicated the heat with a larger mass, it should maintain the higher temperature for a longer time. According to our suspicion, the cause of it could be the fact that near to the Frostbuster protected apricot planting, an experiment with paraffin

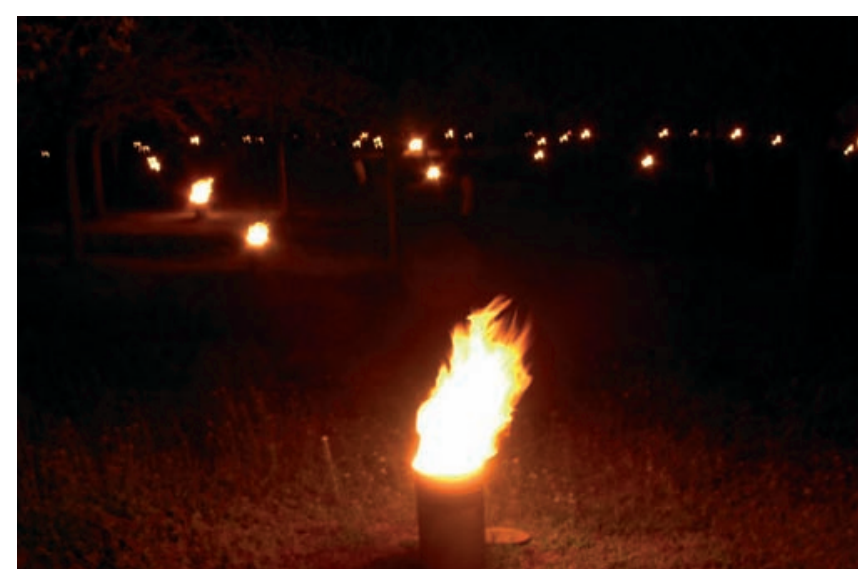

Photo 3 - Burning paraffin candles in the intense apricot plantation at April 9-10, 1012

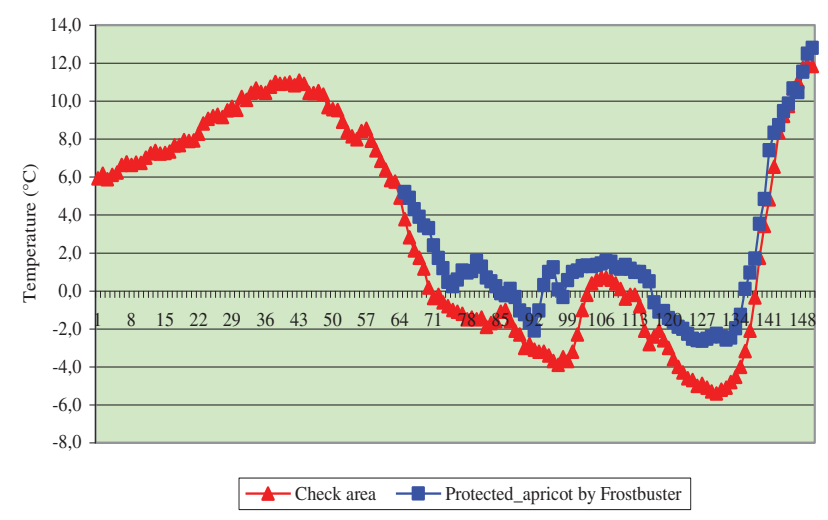

Figure 5 - The temperature regulated and protected by the use of the Frostbuster procedure compared with the check area during the late frost period between April 9. 09.00 and April 10.09.00

candles was performed at the same time. Possibly, the mild air blast pushed the heated air into the Frostbuster protected apricot area. This contributed to the protection of the area.

In Figure 5, it is clearly seen that the start of the activity of Frostbuster ensued two hours after sunset, and the temperature was held with $4{ }^{\circ} \mathrm{C}$ higher than in the check area. At the same time, the temperature dropped on the check area to $-1.7{ }^{\circ} \mathrm{C}$ when the protected was held around $2{ }^{\circ} \mathrm{C}$. The circulation started in early morning, and diminished the effectiveness of the procedure. In the check area, the $3{ }^{\circ} \mathrm{C}$ temperature was paralleled with $-2{ }^{\circ} \mathrm{C}$ as a mean in the protected apricot area. Subsequently, in the neighbouring plantation, where the paraffin candles were used, an air blast raised the temperature from $-2{ }^{\circ} \mathrm{C}$ to $1.8^{\circ} \mathrm{C}$ within half an hour (Figure 5). The minimum temperature early morning when Frostbuster was used was higher by $3{ }^{\circ} \mathrm{C}$ than in the check area. We stated that the Frostbuster procedure is able to protect the area from temperature minima less severe than $-5^{\circ} \mathrm{C}$ for the fruit growers.

Comparing the heat regulating effect of anti frost procedures at Siófok, we may risk the following statements. The treatment with paraffin candles was aimed to avoid the consequences of the lowest temperature in the early morning hours, and it seemed to be less effective than the Frostbuster's in the apricot plantation because the air circulation pushed the heated air to the neighbouring area. Therefore the results were somewhat dubious. The Frostbuster's treatment on the other hand seemed to be inferior in the cherry plantation if we consider the mean temperatures of the treated areas. Taking the mean temperatures of the 8 critical hours of the frost, when the check area showed $-2.3^{\circ} \mathrm{C}$, the protected area by paraffin candles produced $-0.2{ }^{\circ} \mathrm{C}$, whereas that of the Frostbuster's in the intense cherry plantation $-0.9{ }^{\circ} \mathrm{C}$ only (Table 1). However, the highest mean temperatures during the frosty period appeared in the Frostbuster-protected apricot stand: $-0.1^{\circ} \mathrm{C}$. By the addition of the temperatures measured every 10 minutes, a sum of temperatures is received. The most effective procedure is considered where the sum of temperatures of the frosty period produced the lowest values. In the check area the sum was $-153.8^{\circ} \mathrm{C}$. In the Frostbusterprotected cherry plantation $-60.6{ }^{\circ} \mathrm{C}$, whereas in the paraffin 
Table 1 - Temperatures measured during the experiment with two alternative anti-frost procedures at Siófok 2011.04.09-2011.04.10

Temperatures of Frostbuster and paraffin candle protected and check areas (Siófok 2011.04.09-2011.04.10)

\begin{tabular}{|l|c|c|c|c|}
\hline & Check & $\begin{array}{c}\text { Frostbuster- } \\
\text { cherry }\end{array}$ & $\begin{array}{c}\text { Frostbuster- } \\
\text { apricot }\end{array}$ & $\begin{array}{c}\text { Paraffin } \\
\text { candle } \\
\text { apricot }\end{array}$ \\
\hline $\begin{array}{l}\text { Minimum } \\
\text { termperatures }\end{array}$ & -5.4 & -3.1 & -2.6 & -2.7 \\
\hline $\begin{array}{l}\text { Mean temperatures } \\
\text { during the frosty } \\
\text { period }\end{array}$ & -2.3 & -0.9 & -0.1 & -0.2 \\
\hline $\begin{array}{l}\text { Sum of } \\
\text { temperatures } \\
\text { during the frosty } \\
\text { period }\end{array}$ & -153.8 & -60.6 & -5.6 & -14.2 \\
\hline Variability & 1.8 & 1.4 & 1.5 & 1.3 \\
\hline
\end{tabular}

candle-protected apricot area: $-14.2{ }^{\circ} \mathrm{C}$. That means clearly the superiority of the paraffin candle procedure as the value is one fourth of the Frostbuster's. Another area protected by the Frostbuster procedure, the intense apricot plantation produced a sum: $-5.6{ }^{\circ} \mathrm{C}$. Being aware of the circumstances, we may conclude that the combination of the two anti-frost procedures, Frostbuster's and paraffin candle's, increases the effectiveness of frost-protection substantially.

If we consider the reduced variability of temperature during the frosty period, another aspect of the mitigating effect of the procedures could be recognised. The lowest variability is found in the paraffin candle protected area $\left(1.3{ }^{\circ} \mathrm{C}\right)$, whereas the highest variability showed up in the Frostbuster-protected area $\left(1.5{ }^{\circ} \mathrm{C}\right)$. That means also a continuous influence of the neighbouring paraffin candle protected area.

At Pallag, anti-frost irrigation was performed in a plum plantation. Four parallel experiments were planned. In the first, the microjet will activated each 15 minutes for half a minute to moisten the whole surface of the trees. In the second, each ten minute intervals, in the third, each five minutes, in the fourth, each three minutes, always for half a minute. On the trees two platinum sensors were attached, and the means of the two data represented the temperature of the tree.

The treatment of 15 minute spraying intervals during the experiment never cooled down below $-2{ }^{\circ} \mathrm{C}$ (Figure $6)$. Heat released by freezing plus the temperature of water used maintained the frostless $\left(0{ }^{\circ} \mathrm{C}\right)$ conditions until the temperature reached $-3{ }^{\circ} \mathrm{C}$. Below $-3{ }^{\circ} \mathrm{C}$, the steep cooling process $\left(0.1-0.2{ }^{\circ} \mathrm{C}\right.$ per minute) the released heat could not keep the temperature above $0^{\circ} \mathrm{C}$ on the surface of the tree.

As a result of the spray, a several $\mathrm{cm}$ thick ice layer appeared on the surface of woody parts, leaves and inflorescences of trees if the trees were in full bloom. At Pallag, however, the same plantation received earlier a spray treatment in order to delay blooming, therefore the trees did not reach the full bloom stage yet (Photo 4).

The spray treatment with 10 minute intervals did not allow the cooling process to get below $-1.5^{\circ} \mathrm{C}$ (Figure 7).

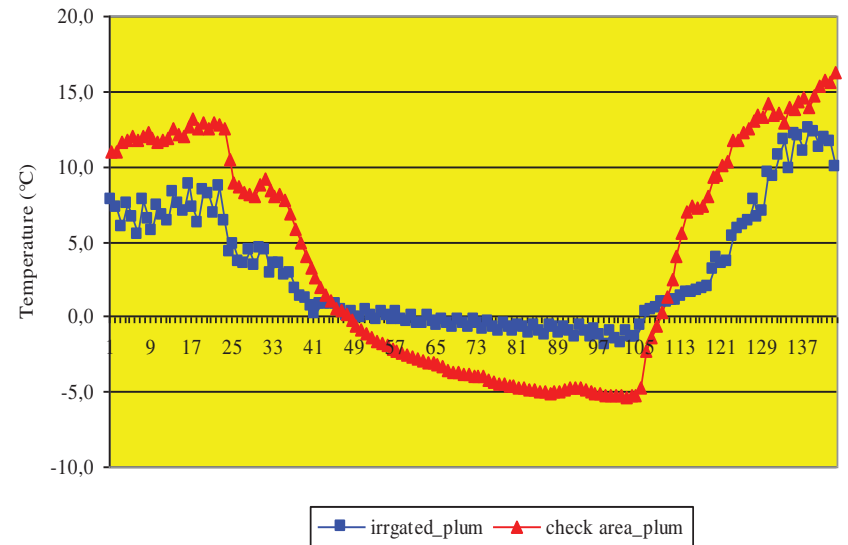

Figure 6 - Temperatures as changing in the spraying experiment with 15 minute intervals (blue) related to the check area (red) at Pallag between April 9. 09.00 and 10. 09.00, 2012

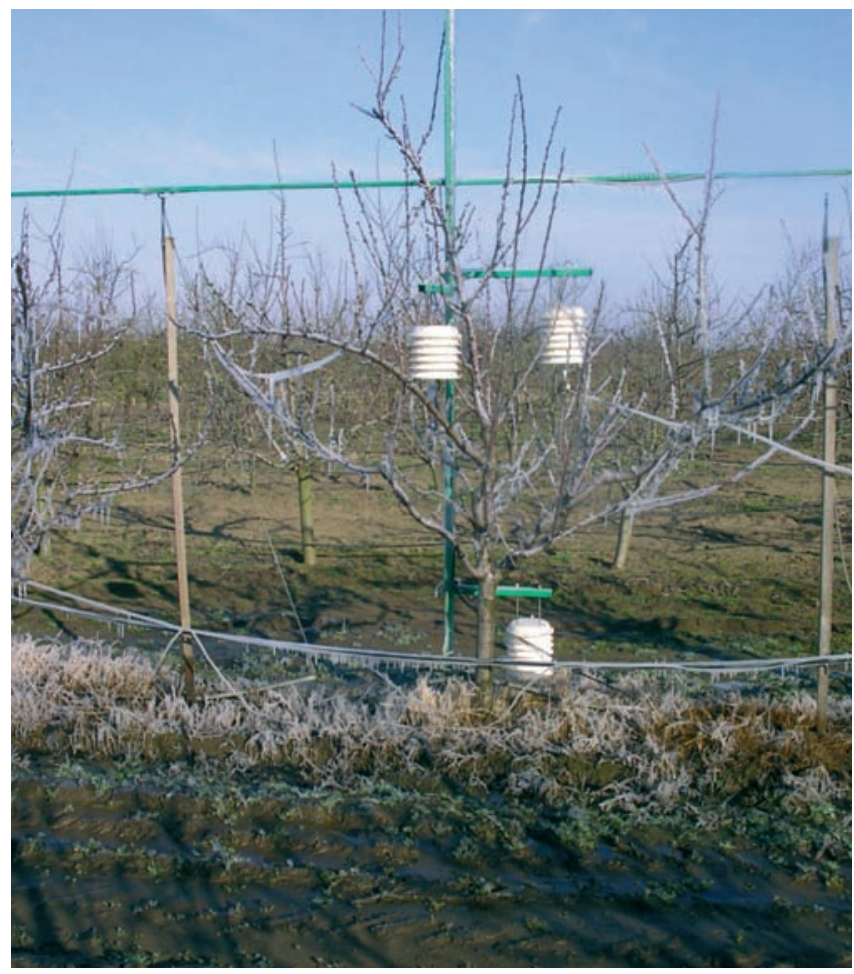

Photo 4 - Result of the anti-frost spray treatment in a plum plantation at Pallag 2012 April 9-10

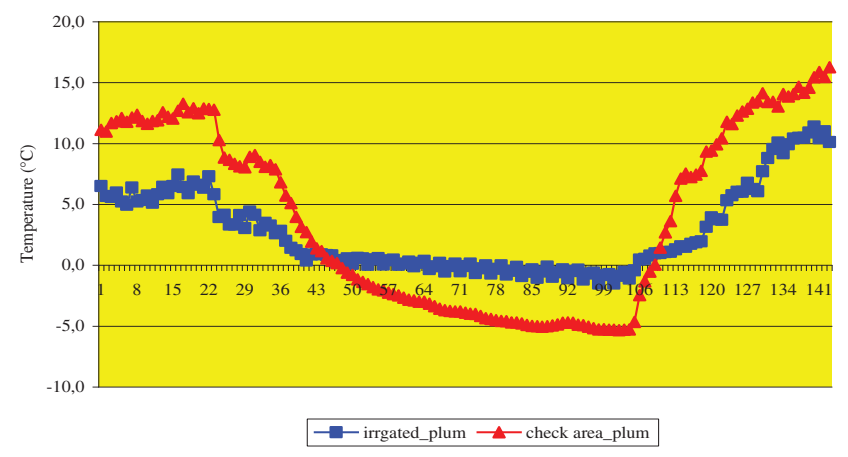

Figure 7 - Temperatures as changing in the anti-frost spraying experiment with 10 minute intervals (blue) related to the check area (red) at Pallag between April 9. 09.00 and 10. 09.00, 2012. 


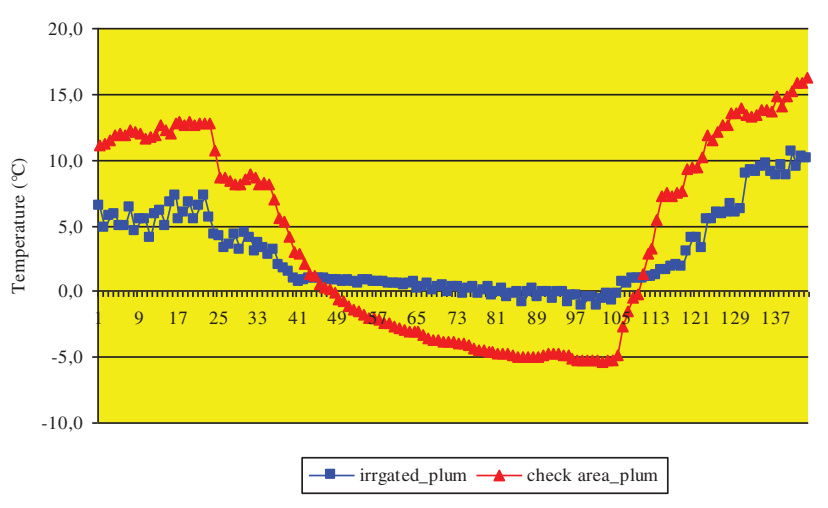

Figure 8 - Temperatures as changing in the spraying experiment with 5 minute intervals (blue) related to the check area (red) in the plum plantation at Pallag between April 9. 09.00 and 10. 09.00, 2012.

We concluded that the heat produced by the freezing process plus the temperature of the water used were efficient to keep the temperature above $0{ }^{\circ} \mathrm{C}$ until $-4{ }^{\circ} \mathrm{C}$ in the check treatment.

In the treatment with 5 minute intervals, the temperature did not drop below $-1.1{ }^{\circ} \mathrm{C}$ during the whole night (Figure 8 ). Heat released by freezing plus water temperature used together secured the plants from freezing until $-5{ }^{\circ} \mathrm{C}$ if the spray has been working through 5 minute intervals. The protective effect is extended even further as $-1.1{ }^{\circ} \mathrm{C}$ is still less deleterious.

The treatment, which means 3 minute intervals between sprays secured protection during the night, when at the deepest point, the temperature did not cool below $-0.4{ }^{\circ} \mathrm{C}$ (Figure 9). The heat released by freezing plus the temperature of water used together was sufficient to save the plants from frost damage until $-5{ }^{\circ} \mathrm{C}$. The measured $-0.4{ }^{\circ} \mathrm{C}$ temperature did not cause physiological damage

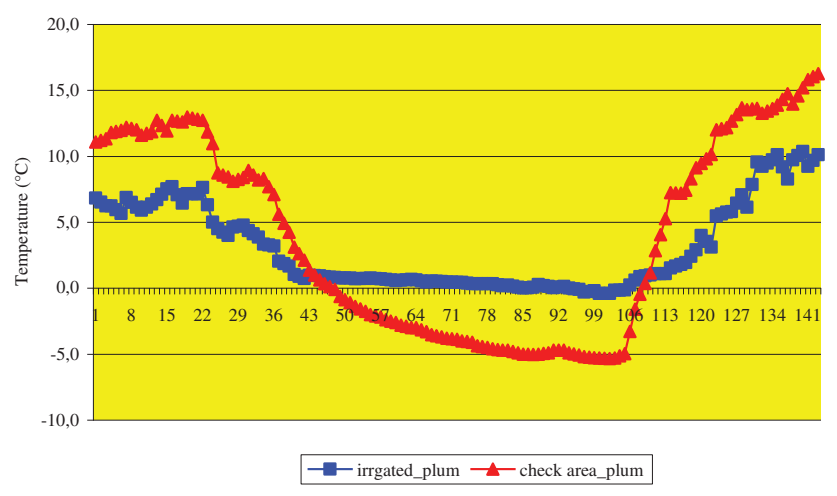

Figure 9-Temperatures as changing in the spraying experiment with 3 minute intervals (blue) related to the check area (red) at Pallag between April 9. 09.00 and 10. 09.00, 2012.

If we compare the effects of the anti-frost treatments with different intervals between the sprays, we are able to present the following conclusions. As for the regulated temperature, the most efficient was the treatment with 3 minute spraying intervals. Therefore, the deeper frosts are threatening, the more frequently the spraying treatments ought to be repeated.
For $-3{ }^{\circ} \mathrm{C}$ minima, the 15 minute interval would be sufficient, for $-4{ }^{\circ} \mathrm{C}$ minima the 10 minute intervals, for -5 ${ }^{\circ} \mathrm{C}$ minima the 5 minute intervals would be recommended, which were suitable e.g. for the frost sensitive apricot plantations. Practically, it means that the monitoring of the temperature should be coordinated with the steering of the sprayers.

The frosty period lasted nearly 8 hours, and the mean temperature of the period was $-3.7^{\circ} \mathrm{C}$, and the trees sprayed with 15 minute intervals were not cooled below $-0.6{ }^{\circ} \mathrm{C}$, and those sprayed with 5 minute intervals were kept at $0.1^{\circ} \mathrm{C}$. An efficient frost protection means not a permanent protection over $0{ }^{\circ} \mathrm{C}$ because permanent mean of $-1{ }^{\circ} \mathrm{C}$ temperature still would not cause frost damage. The feasibility of frost protection with the technique described could be accepted for the fruit growing practice (Table 2).

Table 2 - The temperatures measured in the anti frost treatment's protected areas, with Frostbuster and with paraffin candle at

Siófok 2011.04.09-2011.04.10

\begin{tabular}{|l|r|r|r|r|r|}
\hline \multicolumn{5}{|c|}{$\begin{array}{l}\text { Temperature raised by anti-frost spraying treatments } \\
\text { (Pallag 2011.04.09-2011.04.10) }\end{array}$} \\
\hline & Check & $\begin{array}{l}\text { 15 minute } \\
\text { intervals }\end{array}$ & $\begin{array}{c}\text { 10 minute } \\
\text { intervals }\end{array}$ & $\begin{array}{c}\text { 5 minute } \\
\text { intervals }\end{array}$ & $\begin{array}{c}\text { 3 minute } \\
\text { intervals }\end{array}$ \\
\hline $\begin{array}{l}\text { Minimum } \\
\text { temperatures }\end{array}$ & -5.3 & -1.9 & -1.5 & -1.1 & -0.4 \\
\hline $\begin{array}{l}\text { Mean } \\
\text { temperatures } \\
\text { during the } \\
\text { frosty period }\end{array}$ & -3.7 & -0.6 & -0.2 & 0.1 & 0.3 \\
\hline $\begin{array}{l}\text { Sum of } \\
\text { temperature } \\
\text { during the } \\
\text { frosty period }\end{array}$ & -131.4 & -35.1 & -14.8 & 6.7 & 19.2 \\
\hline Variability & 1.3 & 0.5 & 0.6 & 0.5 & 0.3 \\
\hline
\end{tabular}

By adding the values measured at 10 minute intervals, we may trace the change of temperature during the frosty night. Where the sum of temperature was the lowest, that procedure was the most successful. The sum of temperature was the highest on the check area: $-1538{ }^{\circ} \mathrm{C}$. In the treatment with the Frostbuster in the intense cherry plantation the sum was $-60.6{ }^{\circ} \mathrm{C}$, in the paraffin candle treatment of apricot $-14.2{ }^{\circ} \mathrm{C}$. It means that paraffin candles were four times more efficient than the Frostbuster's procedure. The intense apricot plantation protected by the Frostbuster showed a sum of temperature $-5.6{ }^{\circ} \mathrm{C}$. We concluded that the combination of paraffin candles with Frostbuster's may increase the efficiency of the procedures.

The variability of the temperatures measured during the frosty period in the protected as well as in the check area suggests that the protection reduced the variation. The lowest variability appeared in the paraffin candle treatment $\left(1.3^{\circ} \mathrm{C}\right)$, while the highest was detected in the Frostbuster protected intense apricot plantation $\left(1.5^{\circ} \mathrm{C}\right)$. It means that the heat imported from the paraffin candle treatment to the side of the Frostbuster's was continuous. 


\section{Conclusions}

As the most efficient anti-frost procedure in fruit growing proved to be the spraying with microjets. As long as we are able to regulate dynamically the frequency of activating the irrigation system and the volume of water, the method is thrifty and successful during the late frosts threatening the fruit trees around the sensitive blooming period. As an effective alternative is the Frostbuster's preferably used for avoiding less severe late night frosts, but it is highly sensitive to accidental air circulations. The use of paraffin candles proved to be superior compared with the Frostbuster, but it is also sensitive to moving air, and it is the most costly method. The results allow also the conclusion that a combination of the two latter procedures may increase their efficiency substantially.

\section{Acknowledgement}

This study is funded by TECH_08-A3/2-2008-0373 and TECH_08-A4/2-2008-0138 projects.

\section{References}

Allen, C.C. (1957): A simplified equation for minimum temperature prediction. Mon. Wea. Rev. 85: 119-120.

Anconelli, S., Zinoni, F. (1998): Prime valutazioni sull_efficacia di alcuni microirrigatori, statici e dinamici, da impiegare per I_irrigazione antibrina sottochioma. Rivista di irrigazione e Drenaggio, Edagricole, Bologna, 3: 37-42.

Angus D E. (1955): The use of heaters for frost prevention in a pineapple plantation. Australian Journal of Agricultural Research, 6: 186-195.

Bates, E.M., Lombard, P.B. (1978): Evaluation of temperature inversions and wind machine on frost protection in southern Oregon. Agric. Exp. Sta. Special Report 514, Oregon State University.

Brooks F A. (1961): Frost Control. Agricultural Engineers Handbook. McGraw-Hill. Inc., New York. pp. 532-534.

Cordy C B. (1965): Frost protection in pear orchards with overcrop sprinklers. Special Report 196, Oregon State University, Corvallis, USA.

Davies F S, Jackson L K, Rippetoe L W. (1984): Low volume irrigation and tree wraps for cold protection of young halmin orange trees. Proceeding of the Florida State Horticultural Society, 97: 25-27.

Doesken, N.J., McKee, T.B., Renquist, A.R. (1989): A climatological assessment of the utility of wind machines for freeze protection in mountain valleys. J. Appl. Meteorol. 28 (3): 194-205.

Evans, R.G. (2000): The art of protecting grapevines from low temperature injury. In: Proc. Am. Soc. for Enol. Vitic., 50th Anniversary Meeting, Seattle, WA, June 19-23, pp. 60-72.
Gerber, J.F. (1979): Mixing the bottom of the atmosphere to modify temperatures on cold nights. [In: Barfield, B.J., Gerber, J.F. (Eds.), Modification of the Aerial Environment of Crops.] Am. Soc. Agric. Eng. Monogr. 2, St. Joseph, MI, 315-324.

Gerber J. F., Martsolf J. D. (1979): Sprinkler irrigation for frost and cold protection. In: Modification of Arial Environment of Crops. American Society of Agricultural Engineering (ASAE), St Joseph, Michigan. pp. 327-333.

Goodall, G.E., Angus, D.E., Leonard, A.S., Brooks, F.A. (1957): Effectiveness of wind machines. Calif. Agric. 11 (8): 7-9.

Hagood, L.B. (1967): An empirical method for forecasting radia tion temperatures in the Lower Rio Grande Valley of Texas, Southern Regional Technical Memo. No. 33, National Weather Service.

Iglesias, J. Salvia, L. Torguet and C. Cabús (2002): Orchard cooling with overtree microspinkler irrigation to improve fruit colour and quality of 'Topred Delicious' apples, Sci. Hortic. 93: $39-51$.

Iglesias I., Salvia J., Torguet L., and Montserrat R. (2005): The evaporative cooling effects of overtree microsprinkler irrigation on 'Mondial Gala' apples Scientia Horticulturae, 103, (3): 267-287.

Iglesias I., Echeverría G., Soria Y. (2008): Differences in fruit colour development, anthocyanin content, fruit quality and consumer acceptability of eight 'Gala' apple strains Scientia Horticulturae, 119, (1): 32-40.

Lakatos L., Soltész M., Gonda I., Sun-Zhong-fu., Szabó Z., Nyéki J. (2011): Virágzáskésleltetés és mikroklíma módosítás hütő-öntözéssel, cseresznye-, őszibarack és szilvaültetvényben. „Klíma-21” Füzetek 64: 54-61.

Lakatos, L., Ancza, E., Szél, J., Soltész, M., Szabó, Z. \& Nyéki, J. (2011): The tests of effectiveness of Frostbuster under excessive weather conditions in an apricot plantation, International journal of Horticultural Science. 17. (4-5): 87-92

Renquist, A.R. (1985): The extent of fruit bud radiant cooling in relation to freeze protection with fans. Agric. For. Meteorol. 36 (1): $1-6$.

Reese, R.L., Gerber, J.F. (1969): An empirical description of cold protection provided by a wind machine. J. Am. Soc. Hortic. Sci. 94: 697-700.

Ribeiro, A.C., de Melo-Abreu, J.P., Snyder, R.L. (2006): Apple orchard frost protection with wind machine operation. Agric. For. Meteorol. 141. (2-4): 71-81.

Schmidlin, T.W. (1989): A climatology of shallow winter temperature inversions in Lake Erie vineyards. In: Proceedings of the 19th Conference on Agricultural and Forest Meteorology and the Ninth Conference on Biometeorology and Aerobiology, Charleston, SC, pp. 6-9.

Snyder, R.L., de Melo-Abreu, J.P. (2005): Frost Protection: Fundamentals, Practice, and Economics, Vol. 1. FAO, Rome.

White, G.G., Hass, J.E. (1975): Assessment of Research on Natural Hazards. The MIT Press, Cambridge, MA. 